\title{
Geologia, petrografia e geoquímica das rochas metavulcânicas ácidas da Estrada Real, Rio de Contas (BA)
}

\author{
Josiene Maria de Almeida SANTOS', Adriane MACHADO ${ }^{1,2}$, Cristine LENZ², Leidiane \\ Cerqueira de Carvalho de LIZ1', Igor Antônio Alves da COSTA² \\ 1 Programa de Pós-Graduação em Geociências e Análise de Bacias, Universidade Federal de Sergipe. \\ Cidade Universitária Prof. José Aloísio de Campos. Av. Marechal Rondon, s/n, Jd. Rosa Elze, São \\ Cristóvão, CEP 49100-000, Aracaju, SE, Brasil (josyy42@hotmail.com, adrianemachado@yahoo.com.br, \\ leidiane.cerqueira@gmail.com). \\ 2 Departamento de Geologia, Universidade Federal de Sergipe. Cidade Universitária Prof. José Aloísio de \\ Campos Av. Marechal Rondon, s/n, Jd. Rosa Elze, São Cristóvão, CEP 49100-000, Aracaju, SE, Brasil \\ (adrianemachado@yahoo.com.br, crislenz@yahoo.com.br, igor.iaac@gmail.com).
}

\begin{abstract}
Resumo. Ao longo da Estrada Real, no município de Rio de Contas (BA), afloram rochas metavulcânicas ácidas representativas da Formação Novo Horizonte, Supergrupo Espinhaço, que se formaram na fase sin-rifte do Espinhaço. Estas rochas foram submetidas a intensos processos de deformação e metamorfismo, que modificaram as suas feições originais. Este trabalho visa compreender a gênese do magmatismo ácido sin-rifte do Espinhaço e os processos metamórficos e hidrotermais que afetaram a região, com base em dados de campo, petrográficos e geoquímicos de rocha total. As metavulcânicas ácidas possuem mineralogia constituída por blasto-pórfiros de quartzo, porfiroblastos de andaluzita e cianita, pseudomorfos de granada, feldspatos, biotita, muscovita, sericita, clorita, epidoto, monazita, zircão e minerais opacos imersos em uma matriz quartzo-feldspática. Os processos de sericitização e muscovitização estão presentes nas rochas e indicam a ocorrência de alterações hidrotermais. De acordo com as características petrográficas e geoquímicas, os protólitos das rochas metavulcânicas ácidas foram classificadas como riolitos. Os diagramas de Harker mostram valores dispersos dos elementos maiores $\mathrm{Ca}$, $\mathrm{Na}$ e $\mathrm{K}$ e dos LILEs, indicando uma provável mobilidade desses elementos. No diagrama multielementar de elementos-traço e ETRs são visualizadas anomalias negativas de Nb-Ta, Sr, P e Eu, além de enriquecimento de ETRL em relação aos ETRP. A formação dessas rochas em um ambiente de rifte continental é sugerida, a partir de um processo de fusão crustal com a interação de um manto previamente modificado por zona de subducção (manto metassomatizado).
\end{abstract}

Palavras-chave. Metavulcânicas ácidas, Brechas vulcânicas, Formação Novo Horizonte, Supergrupo Espinhaço

\begin{abstract}
GEOLOGY, PETROGRAPHY AND GEOCHEMISTRY OF THE ACID METAVOLCANIC ROCKS FROM the Estrada ReAL, Rio de Contas (BA). Along the "Estrada Real", in the Rio de Contas County (BA), outcrop acidic metavolcanic rocks representing the Novo Horizonte Formation, Espinhaço Supergroup. Those rocks were formed in the Espinhaço sin-rift phase. The rocks were submitted to intense deformation and metamorphism processes that modified their original features. This work aims to understand the acid magmatism genesis of Espinhaço sin-rift and the metamorphic and hydrothermal processes that affected the region, based on field, petrographic and whole rocks geochemical data. Acid metavolcanic rocks show mineralogy consisting of quartz blastporphyries, andalusite and kyanite porphyroblasts, garnet pseudomorphs, feldspars, biotite, muscovite, sericite, chlorite, epidote, monazite, zircon and opaque minerals immersed in a quartzfeldspar matrix. The sericitization and muscovitization indicate the occurrence of hydrothermal alterations. According to the petrographic and geochemical characteristics, acidic metavolcanic protoliths were classified as rhyolites. The Harker diagrams show scattered values of the larger elements $\mathrm{Ca}, \mathrm{Na}$ and $\mathrm{K}$ and of the LILEs, indicating a probable mobility of these elements. Negative anomalies of $\mathrm{Nb}-\mathrm{Ta}, \mathrm{Sr}, \mathrm{P}$ and Eu are visualized in the trace-elements and ETRs spider diagrams, in addition to enrichment of ETRL in relation to ETRP. The formation of these rocks in a continental rift environment is suggested, starting from a crustal melting process with the interaction of a mantle previously modified by zone of subduction (mantle metassomatizado).

Keywords. Acidic metavolcanics rocks, Volcanic breccias, Novo Horizonte Formation, Espinhaço Supergroup
\end{abstract}




\section{Introdução}

A região de Rio de Contas está localizada no Sudoeste do Estado da Bahia (BA), onde afloram as rochas metavulcânicas ácidas da Formação Novo Horizonte (Grupo Rio dos Remédios), inseridas no contexto geológico do Supergrupo Espinhaço.

No Estateriano (final do Paleoproterozoico), os estados de Minas Gerais e Bahia foram palco de uma tafrogênese, que gerou sistemas de riftes intracontinentais, aos quais sucederam bacias preenchidas por rochas magmáticas e sedimentares, representativas do Supergrupo Espinhaço (Pedreira, 1994; Dussin \& Dussin, 1995; Danderfer et al., 2009). Na Bahia são reconhecidas as bacias do Espinhaço Setentrional e do Espinhaço Oriental (área de estudo), situadas, respectivamente, a oeste e a leste do Bloco do Paramirim. Segundo Guimarães et al. (2008), a Bacia do Espinhaço Oriental é do tipo rifte-sag e evoluiu segundo três fases tectônicas: pré, sin e pós-rifte, formando a sequência metavulcanossedimentar do Supergrupo Espinhaço, que tem como embasamento, os ortognaisses e migmatitos do Bloco Gavião.

O vulcanismo na região de Rio de Contas corresponde à Formação Novo Horizonte (Grupo Rio dos Remédios), uma sequência vulcânica ácida-intermediária com intercalações de rochas clásticas e piroclásticas. Essas rochas afloram dominantemente na borda oeste e sul da Chapada Diamantina. Na cidade de Rio de Contas afloram ao longo da Estrada Real.

Este vulcanismo é associado ao estágio inicial do rifteamento do Espinhaço, classificado como um vulcanismo peraluminoso e alcalino, datado por Schobbenhaus et al., 1994 em torno de $1.748 \mathrm{Ma}$ (idade U-Pb em zircão). Os processos pós magmáticos registrados nessas rochas são o metamorfismo de baixo a médio grau e o hidrotermalismo, que ocorrem distribuídos de forma heterogênea na área. Esses eventos são atribuídos à Orogênese Brasiliana (Guimarães et al., 2008).

Este trabalho tem o propósito de contribuir com o estudo petrológico e geoquímico das rochas metavulcânicas ácidas da Estrada Real, no município de Rio de Contas. Essa região carece de estudos aprofundados, sendo os resultados obtidos nesse trabalho de fundamental importância para a compreensão das características do magmatismo ácido que ocorreu no início da abertura do rifte do Espinhaço.

\section{2 Área, materiais e métodos}

\subsection{Contexto geológico regional}

A área de estudo está inserida na porção central do Cráton do São Francisco, que corresponde ao segmento crustal consolidado entre o Arqueano e o Paleoproterozoico. Este segmento crustal se localiza na porção centroleste da Plataforma Sul-Americana abrangendo principalmente, os estados da Bahia e de Minas Gerais (Almeida, 1977). O Cráton São Francisco é truncado por um rifte intracontinental, que engloba todas as feições e unidades expostas nas regiões da Serra do Espinhaço Setentrional e da Chapada Diamantina. Trata-se de um rifte ensiálico, de orientação geral NNW/SSE, desenvolvido na porção norte do Cráton São Francisco durante o Proterozoico (Cruz \& Alkmim, 2006), que apresenta, como unidades de preenchimento, os supergrupos Espinhaço e São Francisco (Barbosa et al., 2003; Cruz et al., 2007).

$\mathrm{Na}$ Bahia, o Supergrupo Espinhaço é compartimentado em dois grandes domínios fisiográficos: Domínio do Espinhaço Setentrional, a oeste, e o Domínio da Chapada Diamantina, a leste. Ambos estão separados pelo Bloco do Paramirim. A área de estudo localiza-se no Domínio Chapada Diamantina, porção ocidental, onde o Supergrupo Espinhaço é representado, da base para o topo, pelas seguintes unidades: Formação Serra da Gameleira, Grupo Rio dos Remédios (Formações Novo Horizonte, Lagoa de Dentro e Ouricuri do Ouro) e pelo Grupo Paraguaçu, que engloba as formações Mangabeira e Açuruá (Guimarães et al., 2008).

O embasamento da região é representado pelo Bloco Gavião, com rochas de idade variando entre 3,5-2,7 Ga (Barbosa \& Sabaté, 2003), é constituído por três unidades geológicas principais: (1) terrenos graníticos-gnáissicosmigmatíticos, que correspondem à associações 
plutônicas de tonalitos, trondhjemitos e granodioritos (TTG) e granitos arqueanos; (2) sequências supracrustais interpretadas por associações vulcanossedimentares, compostas por unidades vulcânicas ultramáficas, máficas e intermediárias, formações ferríferas bandadas (BIF), rochas carbonáticas, calcossilicáticas e sedimentação terrígena metamorfisada na fácies xisto verde a anfibolito; e (3) rochas plutônicas granitóides do paleoproterozóico, filiação cálcioalcalina e intrusivas nos terrenos TTG e nas associações vulcanossedimentares (BastosLeal, 1998).

$\mathrm{Na}$ Bahia, o Supergrupo Espinhaço foi interpretado como um rifte intracontinental (Jardim de Sá, 1981; Dussin \& Dussin, 1995), que se instalou por volta de 1,75 Ga (Schobbenhaus, 1996) no Estateriano, final do Paleoproterozoico. A Bacia Espinhaço Oriental, Domínio Chapada Diamantina, é do tipo rifte-sag (Martins-Neto, 1998, 2000; Guimarães et al., 2008), que se caracteriza por apresentar uma fase rifte seguida de uma fase flexural, devido à mudança no regime de subsidência de mecânico para termal, sem evoluírem para um estágio de margem passiva, com o desenvolvimento de centros de espalhamento oceânico (Allen \& Allen, 1990). A Bacia Espinhaço Oriental evoluiu segundo três fases tectônicas: (1) pré-rifte, composta pela Formação Serra da Gameleira; (2) sin-rifte, formada pelo Grupo Rio dos Remédios (Formação Novo Horizonte, Lagoa de Dentro e Ouricuri do Ouro); e fase (3) pós-rifte, representada pelas formações Mangabeira e Açuruá pertencentes ao Grupo Paraguaçu (Fig. 1B). A abordagem geral da geologia da área de estudo será feita com base em Guimarães et al.(2008) e Barbosa (2012).

AFormaçãoSerradaGameleiraéconstituída por três associações de litofácies siliciclásticas: (1) metaquartzo-arenitos grossos a finos e metargilitos laminados; (2) metaconglomerados polimíticos e oligomíticos, metarenitos médios a granulosos com estratificação acanalada; e (3) metaquartzo-arenitos com estratificação cruzada do tipo acanalada de grande porte com níveis de metabrechas, metagrauvacas e metarcóseos (Guimarães et al., 2008).

A Formação Serra da Gameleira é interpretada como uma sequência deposicional, que representa a fase que precede a instalação de uma bacia rifte no paleocontinente São Francisco, no Estateriano. A unidade representa o período de adelgaçamento da crosta continental da região, com formação de bacia flexural, pré-vulcanismo e pré-rompimento litosférico (Barbosa, 2012).

O Grupo Rio dos Remédios é uma sequência metavulcanossedimentar com idade de 1,75 Ga (Schobbenhaus, 1996), que representa a fase sin-rifte da evolução tectônica da Bacia Espinhaço Oriental e é composta, da base para o topo, pelas formações Novo Horizonte, Lagoa de Dentro/Ouricuri do Ouro.

A Formação Novo Horizonte é constituída por rochas metavulcânicas, metasubvulcânicas, metapiroclásticas e metaepiclásticas, e apresenta-se como colinas e serras alongadas a estreitas, alinhadas na direção NNWSSE (Guimarães et al., 2008). As litologias desta unidade correspondem à metadacitos, metarriolitos, metaquartzos pórfiros e metaandesitos, em geral, bastante modificadas pela deformação e pela ação de fluidos de origem magmática e metamórfica (Danderfer \& Dardenne, 2002; Barbosa, 2012). Segundo Teixeira (2005), o vulcanismo da Formação Novo Horizonte representa o estágio inicial do rifteamento e corresponde a um magmatismo peraluminoso e alcalino do Tipo A2, com importante contribuição crustal. As idades Ar-Ar de resfriamento de 404 \pm 3 Ma e 499 \pm 2 Ma, obtidas em muscovitas selecionadas de metarriolitos da Formação Novo Horizonte (Guimarães et al., 2008), atestam a participação do evento Orogenético Brasiliano na reestruturação das bacias, que abrigam os depósitos do Supergrupo Espinhaço, demonstrando que essas rochas foram metamorfisadas e deformadas no Evento Brasiliano.

A Formação Lagoa de Dentro/Ouricuri do Ouro representa a unidade superior do Grupo Rio dos Remédios formada basicamente, por uma sedimentação terrígena composta por metarritimitos, metaconglomerados polimíticos, metarenitos, metarcóseos, metagrauvacas e metaquartzo-arenitos. Esta sequência metassedimentar foi formada por fluxos gravitacionais e trativos relacionados à um sistema aluvial, que posteriormente foi 
retrabalhado por um sistema eólico (Guimarães et al., 2008).

O Grupo Paraguaçu corresponde a fase pós-rifte na Bacia Espinhaço Oriental, caracterizada por uma sedimentação regulada por subsidência mecânica passiva. Os depósitos relacionados a essa fase correspondem às formações continental costeira/marinha rasa Mangabeira/Açuruá (Danderfer \& Dardenne, 2002; Guimarães et al., 2008; Danderfer et al., 2009).

A Formação Mangabeira é representada por rochas siliciclásticas, que correspondem a uma espessa sedimentação continental costeira, associada à tratos de sistemas de mar baixo, com metarenitos/metaquartzo-arenitos com estratificação cruzada de grande porte, geradas por processos eólicos e metarenitos com estratificação cruzada acanalada de pequeno a médio porte, formadas por correntes fluviais efêmeras (Guimarães et al., 2008).

A Formação Açuruá é composta por litofácies que compõem dois ciclos de sedimentação granocrescentes ascendentes, acumulados em ambiente marinho raso e litorâneo. O primeiro ciclo começa com metargilitos, passa a metarritimitos e encerrase com metarenitos. O segundo é representado apenas por metarritimitos sugerindo um contexto sedimentar transgressivo, passando a mar alto e diminuição da lâmina de água nesse sentido (Barbosa, 2012).

\subsection{Materiais e métodos}

O trabalho de campo ao longo da Estrada Real foi realizado com base no mapa geológico (CPRM, 2013) e topográfico (IBGE, 2015) da região. Quarenta amostras de rochas metavulcânicas ácidas foram coletadas; vinte e uma amostras foram selecionadas para a confecção de lâminas delgadas no Laboratório de Laminação da Universidade de Brasília (UNB). As descrições macroscópicas e microscópicas foram realizadas no Laboratório de Microscopia e Lupas do Departamento de Geologia (DGEOL) da Universidade Federal de Sergipe, com o auxílio de uma lupa de mesa (marca PHYSIS) e um microscópio petrográfico binocular da marca OLYMPUS BX4. As amostras de rocha selecionadas (sete) para análise química de rocha total foram britadas, moídas (fração < 200 mesh) e analisadas para elementos maiores, traço e terras raras, no Laboratório da GEOSOL (Minas Gerais). Posteriormente, os dados químicos foram tratados utilizando-se os softwares Excel, Petrograph e GCDkit 3.00.

\section{Resultados}

\section{1 Geologia local}

As metavulcânicas ácidas da região de Rio de Contas estão inseridas na Formação Novo Horizonte, que constitui a porção basal do Grupo Rio dos Remédios, e associadas ao desenvolvimento da fase sin-rifte na Bacia Espinhaço Oriental (Martins-Neto, 2000; Guimarães et al., 2008).

As rochas estudadas afloram na Estrada Real, na forma de serras, morros, lajedos e blocos proeminentes, sendo de fácil acesso. $\mathrm{Na}$ área de estudo, além das metavulcânicas da Formação Novo Horizonte, ocorrem rochas sedimentares representativas da Formação Ouricuri do Ouro (Fig. 1C). A Formação Novo Horizonte é representada por duas faciologias: as brechas vulcânicas e as rochas metavulcânicas ácidas (Fig. 2).

As brechas vulcânicas estão posicionadas na base da Formação Novo Horizonte, aflorando na área de estudo, no fim do trecho de calçamento em pedra da Estrada Real, no Balneário Riacho Bonito. As brechas ocorrem na forma de blocos proeminentes e lajedos, e possuem fragmentos líticos imersos em matriz fina (Fig. 2A); apresentam cor cinza escuro e quando alteradas, tonalidade alaranjada ou preta. A matriz possui composição mineralógica composta por quartzo e sericita, epresença de fragmentos líticos angulosos de arenito, cujas dimensões variam de $2 \mathrm{~mm}$ a 9,5 cm. Por vezes, estas rochas apresentam foliação incipiente.

As metavulcânicas ácidas afloram ao longo de praticamente toda a Estrada Real e ocorrem estratigraficamente, no topo das brechas vulcânicas. Apresentam coloração cinza a cinza escuro (Fig. 2B e 2C) e quando alteradas, 

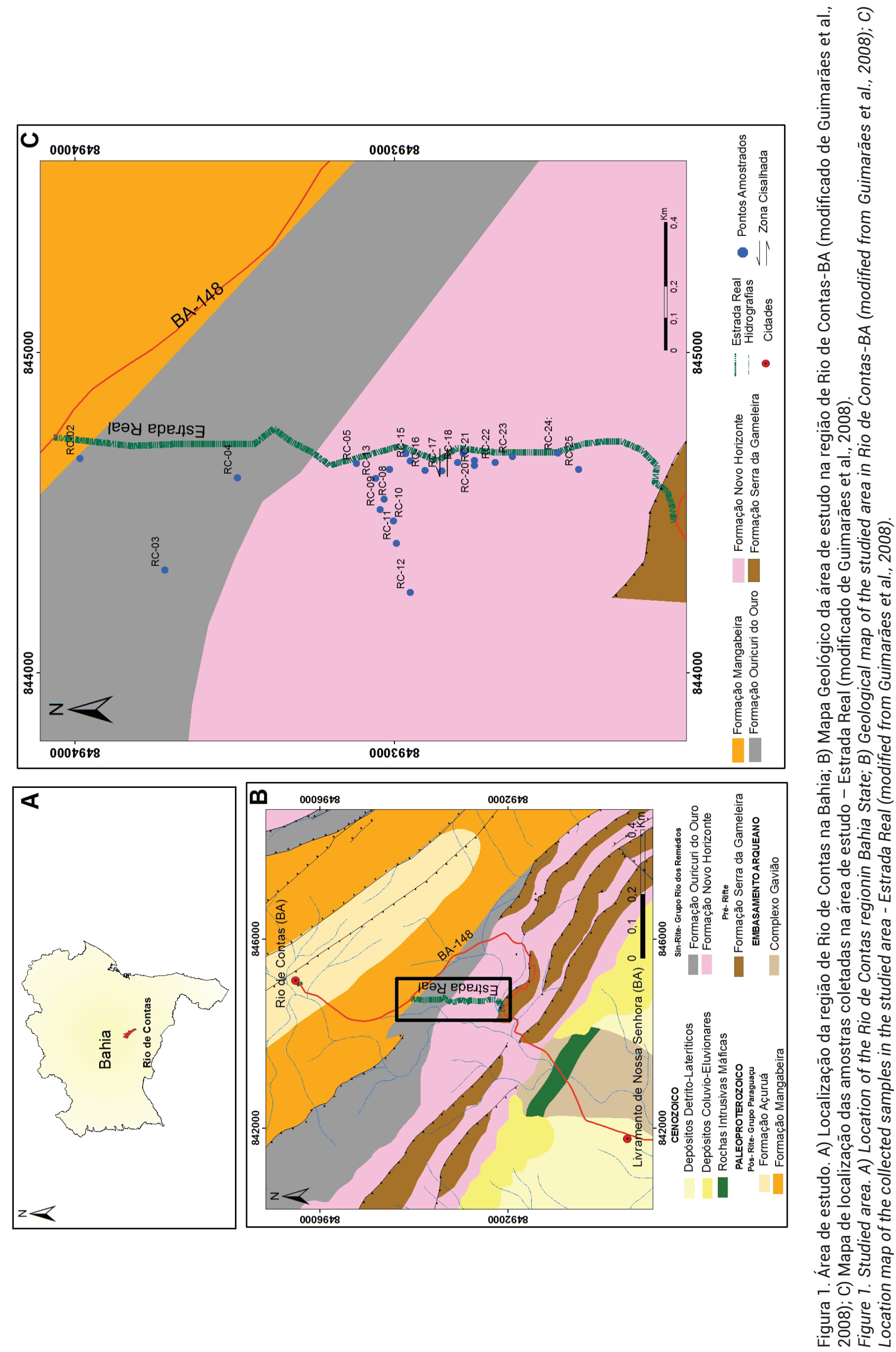


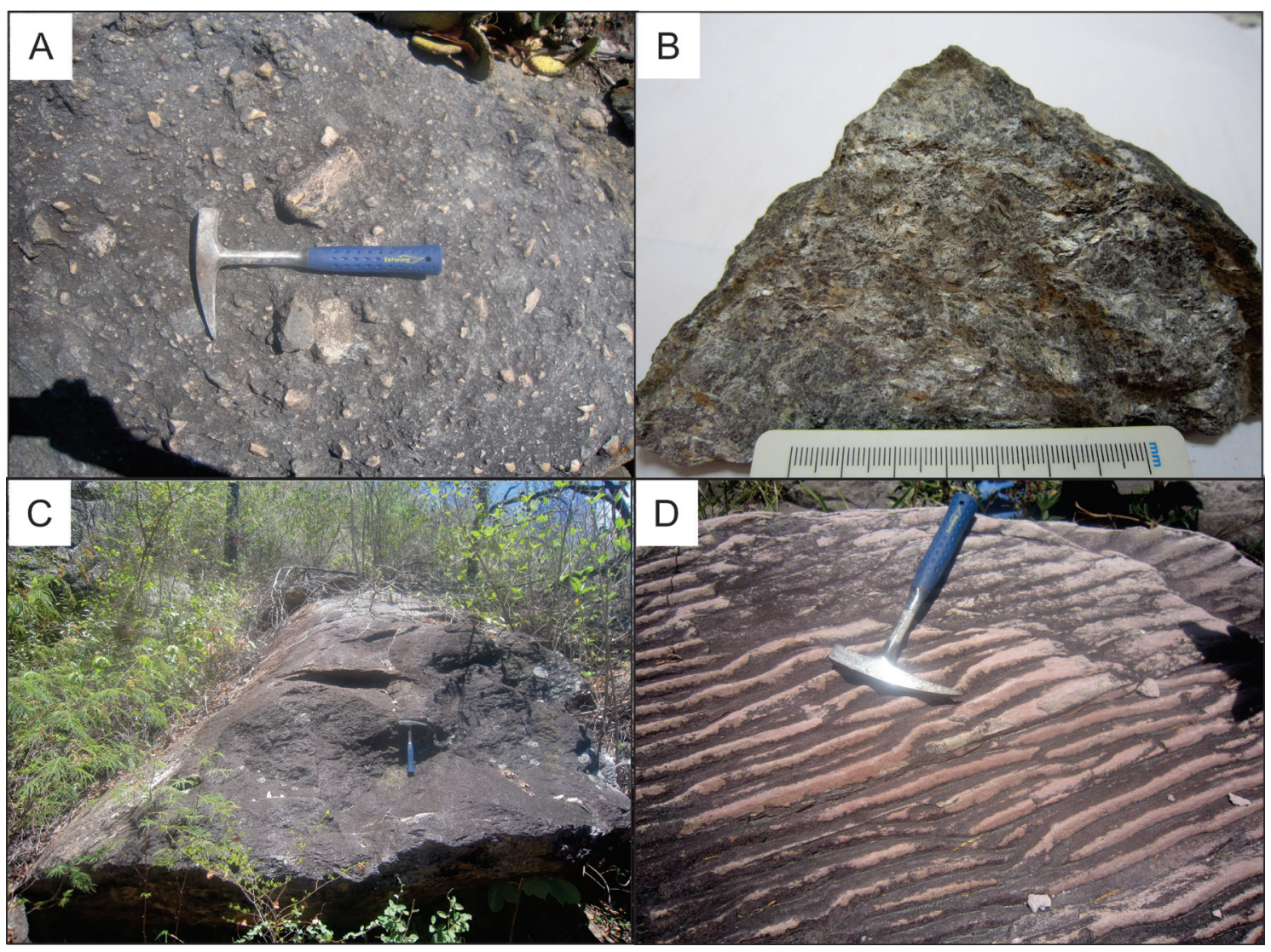

Figura 2. Afloramentos e amostragem da área de estudo. A) Brecha vulcânica com fragmentos líticos (arenito) imersos na matriz; B) Amostra de mão da rocha metavulcânica ácida com coloração cinza; C) Afloramento de metavulcânica ácida. (D) Afloramento de arenito com marcas de onda.

Figure 2. Outcrops and sampling from the studied area. A) Volcanic breccia with lithic fragments (sandstone) immersed in the matrix; B) Acid metavolcanic hand sample showing grey color; C) Acid metavolcanic outcrop; D) Sandstone outcrop with wave-marks.

apresentam tonalidades que variam de alaranjado a avermelhado, amarelo esverdeado e preto. As metavulcânicas são rochas holocristalinas, porfiríticas e/ou afaníticas, com mineralogia constituída por cristais de quartzo, biotita, clorita e sericita. Por vezes, ocorre a presença de vênulas de quartzo em algumas amostras.

A principal feição estrutural das metavulcânicas ácidas é a foliação, que varia de incipiente a bem desenvolvida e ocasionalmente milonítica, além de padrões de fraturamentos em várias direções, registrando um padrão deformacional dúctil e rúptil. A foliação é marcada por cristais de biotita orientados, predominando a foliação incipiente com atitudes NW-SE e médio a alto ângulo de mergulho para SW. Na área de estudo se observa uma zona cisalhada (Fig. 1C), com foliação milonítica concordante com a foliação principal.

$\mathrm{Na}$ parte topográfica mais alta, estratigraficamente acima das metavulcânicas ácidas, afloram os arenitos da Formação Ouricuri do Ouro, sendo o contato por discordância angular.

A Formação Ouricuri do Ouro é representada por arenitos, na forma de blocos proeminentes e lajedos. Essas rochas possuem tonalidade rosada, granulometria média a fina e cor de alteração variando do alaranjado ao avermelhado, amarelo e preto. A mineralogia é composta por quartzo, raros cristais de sericita e óxido de ferro. Nestas rochas ocorrem estratificações plano paralela, marcas de onda (Fig. 2D) e veios de quartzo de espessura milimétrica a centimétrica.

\subsection{Petrografia}

\subsubsection{Metavulcânicas ácidas}

As rochas metavulcânicas ácidas que afloram ao longo da Estrada Real possuem mineralogia composta por quartzo (75-86\%), 
feldspatos $(<5 \%)$, biotita (2-8\%), pseudomorfos de granada (5-8\%), andaluzita (2-5\%), cianita (2$4 \%)$, sericita $(2 \%)$, muscovita $(1,5-4 \%)$, epidoto $(1-1,5 \%)$, clorita $(<1 \%)$ e minerais opacos $(6-8 \%)$, além de zircão $(<1 \%)$, rutilo $(<1 \%)$ e monazita $(<1 \%)$. A matriz das rochas é de composição essencialmente quartzo-feldspática e apresenta concentrações de minerais opacos, muscovita, sericita, epidoto, clorita e carbonato. As texturas observadas são do tipo blasto-porfirítica, porfiroblástica e lepidoblástica.

O quartzo ocorre de duas formas, como porfiroclasto e na matriz da rocha (Fig. 3A). Nas duas formas de ocorrência, o quartzo é subidiomórfico e apresenta dimensão que varia de 0,01 a 0,2 $\mathrm{mm}$ para os cristais da matriz e de aproximadamente $0,6 \mathrm{~mm}$ para os porfiroclastos de quartzo. Os porfiroclastos de quartzo apresentam extinção ondulante, com ocorrência de subgrãos e novos grãos de quartzo. Alguns cristais encontram-se estirados e assimétricos ou com embainhamentos e fraturados. O quartzo da matriz apresenta extinção ondulante e ocorre como subgrãos e novos grãos ou preenchendo fraturas e vênulas. Por vezes, é possível observar feições de dissolução por pressão e presença de sombra de pressão em alguns cristais de quartzo, além de feições de rotação de subgrão e migração de limite de grão.

Os feldspatos (K-feldspato e o plagioclásio) encontram-se pouco preservados, muito alterados para sericita, carbonato e argilominerais. Raramente é possível observar parte da geminação polissintética da albita no plagioclásio.

A biotita ocorre como cristais subidiomórficos, variando de 0,03 a 1,7 mm, que se apresentam bastante alterados por processo de muscovitização. Os cristais de biotita marcam a foliação principal da rocha (Fig. 3B). Em porções da rocha em que ocorre a foliação milonítica, os cristais ocorrem bem alongados e orientados. A foliação engloba porfiroblastos de andaluzita e cianita, pseudomorfos de granada, e também, os porfiroclastos de quartzos. Os cristais de biotita são substituídos por minerais opacos, que ocorrem nas bordas dos cristais ou como inclusões.

A muscovita 1 (metamórfica) ocorre como cristais subdiomórficos, com dimensões entre 0,04 a 0,07 mm. Esses cristais ocorrem ao longo da matriz e geralmente estão em contato com a cianita. Em algumas porções da rocha é possivel observar a presença de mica fish.

Os porfiroblastos de andaluzita são subidiomórficos a xenomórficos, com dimensões variando de 0,5 a 1,5 mm (Fig. 3C), apresentam contatos irregulares a curvos com a matriz. Alguns cristais ocorrem com bordas bastante alteradas. Esses cristais apresentam fraturas, inclusões de quartzo, epidoto, e comumente, estão alterados para sericita.

A cianita ocorre como porfiroblastos subidiomórficos, com dimensões variando de 0,6 a 1,2 mm. Os cristais apresentam inclusões de minerais opacos e por vezes, são substituídos por andaluzita (Fig. 3D). Esses cristais são contornados pela foliação e algumas vezes apresentam-se rotacionados.

Os pseudomorfos de granada (Fig. 3E) ocorrem na forma de porfiroblastos idiomórficos a subdiomórficos, com dimensões entre 0,05 a 1,2 mm. Os cristais de granada são substituídos por minerais opacos e são contornados pela foliação da rocha.

A mineralogia secundária é constituída por cristais de muscovita 2 (hidrotermal), sericita, clorita, epidoto e minerais opacos. A muscovita 2 ocorre como cristais subidiomórficos, com dimensões entre 0,02 a 0,03 mm. Este mineral ocorre como produto de substituição da biotita por processo hidrotermal.

A sericita ocorre de forma subidiomórfica, com dimensões de 0,01 mm, resultante do processo de alteração hidrotermal dos feldspatos (sericitização) e dos porfiroblastos de andaluzita.

A ocorrência de clorita é restrita a poucas amostras. Os cristais são xenomórficos, apresentam cor verde pálido e pleocroísmo de verde pálido a verde escuro, com dimensões variando de 0,01 a 1,7 mm.

Os cristais de epidoto são xenomórficos, com dimensões de 0,02 mm e ocorrem disseminados na matriz da rocha ou associados a clorita.

Os minerais opacos são abundantes na rocha, possuem forma xenomórfica e por vezes, ocorrem como agregados na matriz. Geralmente, 


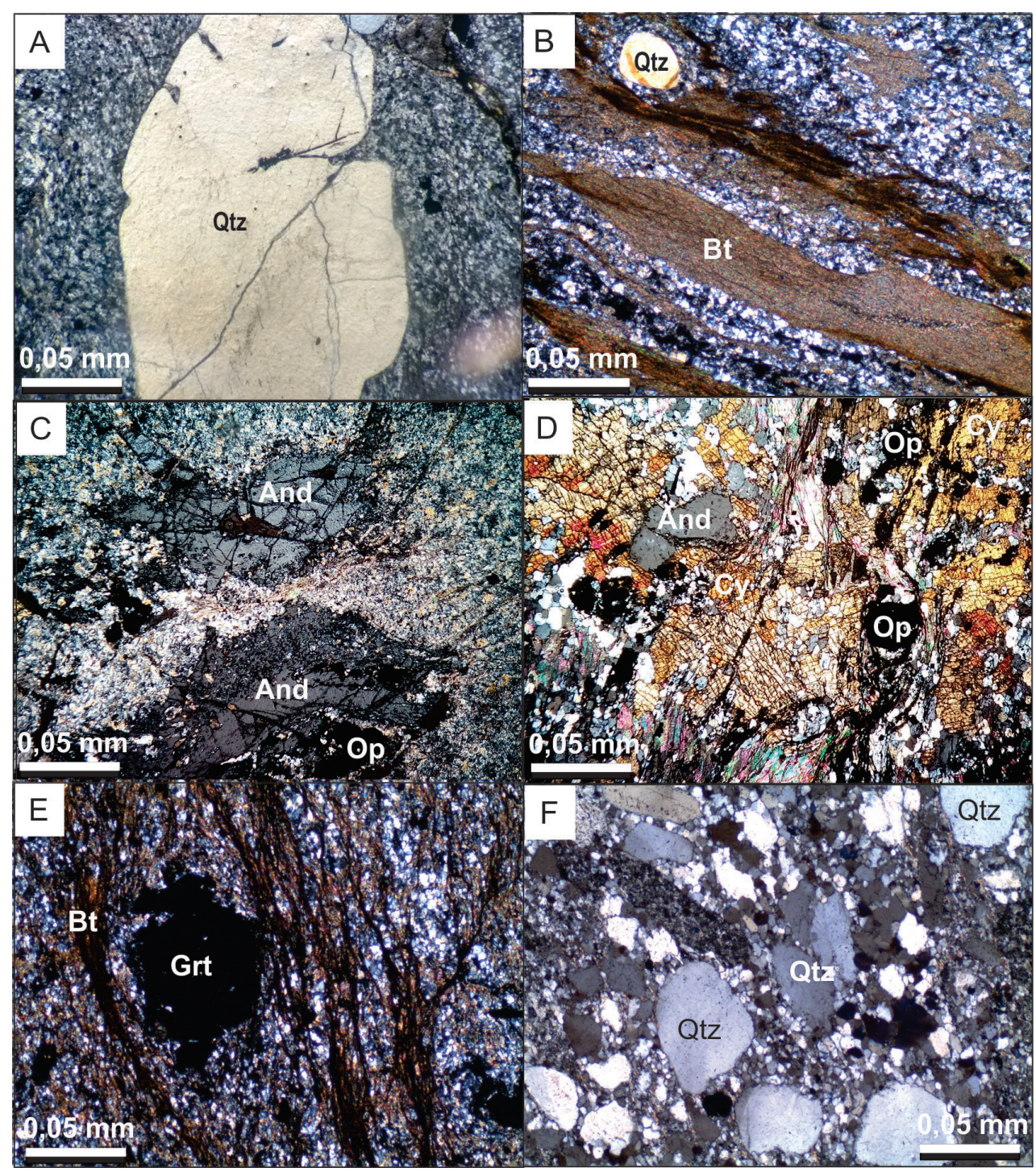

Figura 3. Fotomicrografias das rochas metavulcânicas da Estrada Real. A) Porfiroclasto de quartzo com feições de embainhamento; B) Biotita orientada segundo a foliação da rocha, marcando a textura lepidoblástica; C) Porfiroblasto de andaluzita com bordas alteradas; D) Porfiroblasto de cianita sendo substituída por andaluzita; E) Pseudomorfo de granada; F) Brecha vulcânica com matriz fina e fragmentos líticos angulosos de arenito imersos na matriz. (Abreviações segundo Whitney \& Evans, 2010). Luz polarizada (4X).

Figure 3. Photomicrographs of metavolcanic rocks from Estrada Real. A) Quartz porphyroclast with sheathing features; $B$ ) Moscovitized biotite oriented according to the foliation of the rock, marking the lepidoblastic texture; $C$ ) Andalusite porphyroblast with altered edges; D) Pseudomorphic garnet; E) Kyanite porphyloblast replaced by andalusite; F) Volcanic breccia with fine matrix and sandstone angular fragments immersed in the matrix. (Abbreviations Whitney \& Evans, 2010). Polarized light (4X).

ocorrem associados à biotita e à granada, e também, preenchendo fraturas.

Os minerais acessórios observados são zircão, monazita, apatita e rutilo. O zircão é subidiomórfico e varia entre 0,01 a 0,03 mm. A monazita ocorre como cristais xenomórficos, com dimensão de 0,01 mm. A apatita ocorre como cristais xenomórficos com dimensões de $0,05 \mathrm{~mm}$. O rutilo ocorre de forma xenomórfica com dimensões entre 0,02 a 0,04 mm. Estes minerais ocorrem de forma restrita em algumas amostras.

\subsubsection{Brecha Vulcânica}

A brecha vulcânica (Fig. 3F) possui matriz fina e é constituída essencialmente, por quartzo, muscovita e sericita. Fragmentos líticos (arenito) e grãos de quartzo ocorrem imersos na matriz. Os fragmentos líticos são geralmente angulosos, com dimensões centimétricas e mineralogia composta por quartzo, muscovita, biotita e sericita. Os grãos de quartzo apresentam extinção ondulante e dimensões variando de 0,03 a $0,4 \mathrm{~mm}$. 


\subsection{Geoquímica}

As análises de rocha total para elementos maiores, traço e ETRs foram realizadas em sete amostras, cujos dados litoquímicos encontramse na tabela 1.

As rochas metavulcânicas ácidas da Estrada Real estão bastante alteradas e modificadas pela ação de fluidos magmáticos, primários ou secundários, de origem meteórica ou decorrentes de reações metamórficas relacionadas ao evento tectônico Brasiliano.

Elementos essencialmente imóveis foram utilizados na classificação do protólito ígneo das rochas metavulcânicase na definição da afınidade química dessas rochas, com o objetivo de minimizar qualquer interferência de processos relacionados ao intemperismo, metamorfismo e hidrotermalismo.

No intuito de verificar a mobilidade dos elementos maiores, LILES e HFSE, gráficos binários do tipo Harker foram elaborados, utilizando o elemento imóvel Zr como índice de diferenciação (Fig. 4).

$\mathrm{Na}$ correlação dos óxidos de $\mathrm{CaO}, \mathrm{Na}_{2} \mathrm{O}$ e $\mathrm{K}_{2} \mathrm{O}$ versus $\mathrm{Zr}$ (Fig. 4) foram verificadas grandes
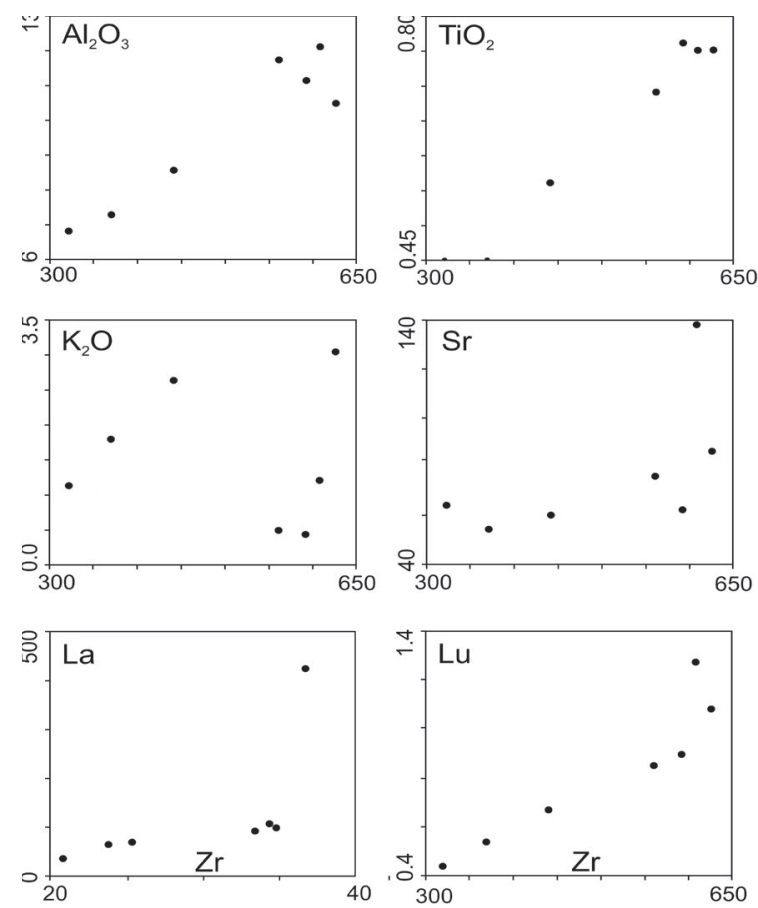

dispersões, além de valores anomalamente baixos para as rochas metavulcânicas ácidas. Da mesma forma, os elementos LILE, com alta mobilidade como $\mathrm{Ba}$ e $\mathrm{Rb}$, também apresentam grande dispersão em relação ao Zr. No diagrama $\mathrm{SiO}_{2}$ versus $\mathrm{Zr}$ observa-se um padrão de correlação negativa, enquanto que para $\mathrm{O} \mathrm{Al}_{2} \mathrm{O}_{3}$ ocorre uma correlação positiva em relação ao Zr. Para os elementos considerados pouco móveis, como o La, Lu e Nb, observa-se também, uma correlação positiva com o Zr.

A classificação litológica das rochas baseada na geoquímica foi dificultada, devido às rochas se encontrarem hidrotermalizadas $e$ com visível subtração dos álcalis. Na tentativa de utilizar elementos traço como índices para a classificação dos protólitos das metavulcânicas, o diagrama Co versus Th (Hastie et al., 2007) foi utilizado e evidencia, que as amostras plotam no campo dos riolitos/dacitos, caracterizando as metavulcânicas ácidas da Estrada real como metarriolitos/metadacitos (Fig. 5). A afinidade geoquímica do magmatismo também é de identificação difícil. Segundo Teixeira (2005), as metavulcânicas ácidas apresentam afinidade alcalina.
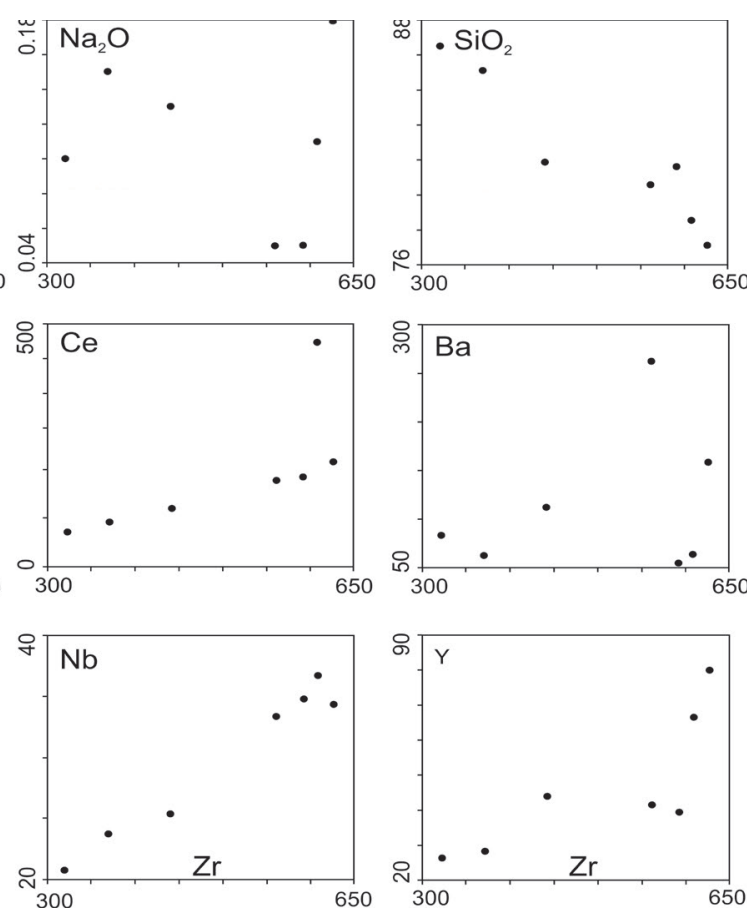

Figura 4. Comparação do Al2O3, TiO2, Na2O, Sr, Ce e Ba versus Zr para avaliação da mobilidade dos óxidos nas rochas metavulcânicas ácidas da Estrada Real.

Figure 4. Comparison of Al2O3, TiO2, Na2O, Sr, Ce e Ba versus $\mathrm{Zr}$ to evaluate the mobility of these oxides in the acidic metavolcanic rocks from Estrada Real. 


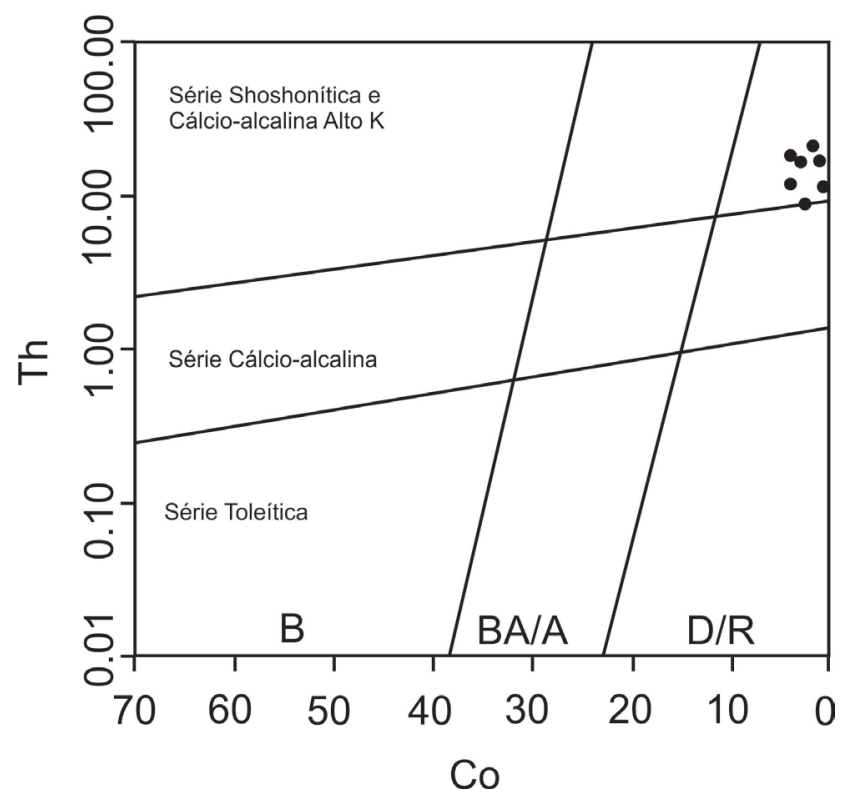

Figura 5. Diagrama de classificação Co versus Th (Hastie et al., 2007), mostrando as amostras plotando no campo dacito/riolito. ( $\mathrm{B}=$ Basalto; $\mathrm{BA} / \mathrm{A}=$ Basalto Andesítico/ Andesito, D/R = Dacito/Riolito).

Figure 5. Co versus Th classification diagram (Hastie et al., 2007) showing the samples plottingin the dacite/rhyolite field. $(B=$ Basalt; $B A / A=$ Andesitic Basalt $/$ Andesite, $D / R=$ Dacite/Rhyolite).

No diagrama multielementar para elementos-traço normalizado pelo Manto Primitivo de Sun \& McDonough (1989) (Fig. 6A), as metavulcânicas ácidas apresentam um empobrecimento em LILEs ( $\mathrm{Rb}, \mathrm{Ba}, \mathrm{Sr}, \mathrm{Ce})$ em relação aos HFSEs. As anomalias negativas de Sr, P e Ti são notáveis, além de anomalias negativas de $\mathrm{Nb}$ e $\mathrm{Ta}$.

O padrão de distribuição dos Elementos Terras Raras (ETR), quando normalizados pelo Condrito de Boynton (1984) (Fig. 6B), mostram que as rochas apresentam enriquecimento em ETRL em relação aos ETRP e anomalia negativa de Eu. A amostra RC-16 apresenta maior enriquecimento em ETRLs em relação aos pesados e anomalia negativa de Ce.

\section{Discussões}

4.1 Considerações acerca dos estudos petrográficos: estágios magmáticos e pósmagmáticos

O trabalho de campo realizado na Estrada Real, município de Rio de Contas, permitiu reconhecer afloramentos de rochas metavulcânicas (metadacitos/metarriolitos) e brechas vulcânicas (rochas piroclásticas) pertencentes à Formação Novo Horizonte. O enfoque deste trabalho é as rochas metavulcânicas ácidas, que ocorrem associadas às sequências de rochas metassedimentares da Formação Serra da Gameleira (porção basal do Supergrupo Espinhaço) e da Formação Ouricuri do Ouro (topo da Formação Novo Horizonte).

Os dados de campo mostraram que em alguns locais da área de estudo, as rochas metavulcânicas ocorrem intercaladas com as rochas metassedimentares (principalmente arenitos). Estas rochas apresentam registros de metamorfismo de baixo grau e deformação dominantemente associada à zonas de cisalhamento.

As rochas metavulcânicas ácidas da Estrada Real possuem mineralogia primária composta por cristais de quartzo, feldspatos, muscovita (1), biotita, pseudomorfos de granada, andaluzita e cianita. Os minerais acessórios são monazita, apatita, rutilo e zircão. Os secundários são representados por clorita, epidoto, muscovita (2), sericita e minerais opacos. A maior parte das amostras possuem porfiroclastos de quartzo imersos numa matriz quartzo-feldspática, representando estes porfiroclastos, um resquício da mineralogia ígnea da rocha. De acordo com Teixeira (2005), uma fração das rochas metavulcânicas são porfiríticas, caracterizadas pela predominância de quartzo arredondado imerso em matriz muito fina. Arcanjo et al. (2000) descrevem as rochas como porfiríticas, com fenocristais de feldspato e quartzo, medindo entre poucos milimetros a $3 \mathrm{~cm}$ de comprimento, envolvidos em matriz com quartzo, feldspato e magnetita.

Os dados petrográficos evidenciam o registro da deformação ocorrida na região. A foliação das metavulcânicas (metadacitos/ metarriolitos) é marcada pela orientação dos cristais de biotita, caracterizando a textura lepidoblástica. Subgrãos e novos grãos de quartzo (Fig. 7A) são observados, além de cristais de quartzo estirados, mica-fish, porfiroblastos de cianita e pseudomorfos de granada rotacionados (Fig. 7B). Estas feições remetem a recristalização e deformação dinâmica e estática associadas às zonas de cisalhamento existentes na área de 

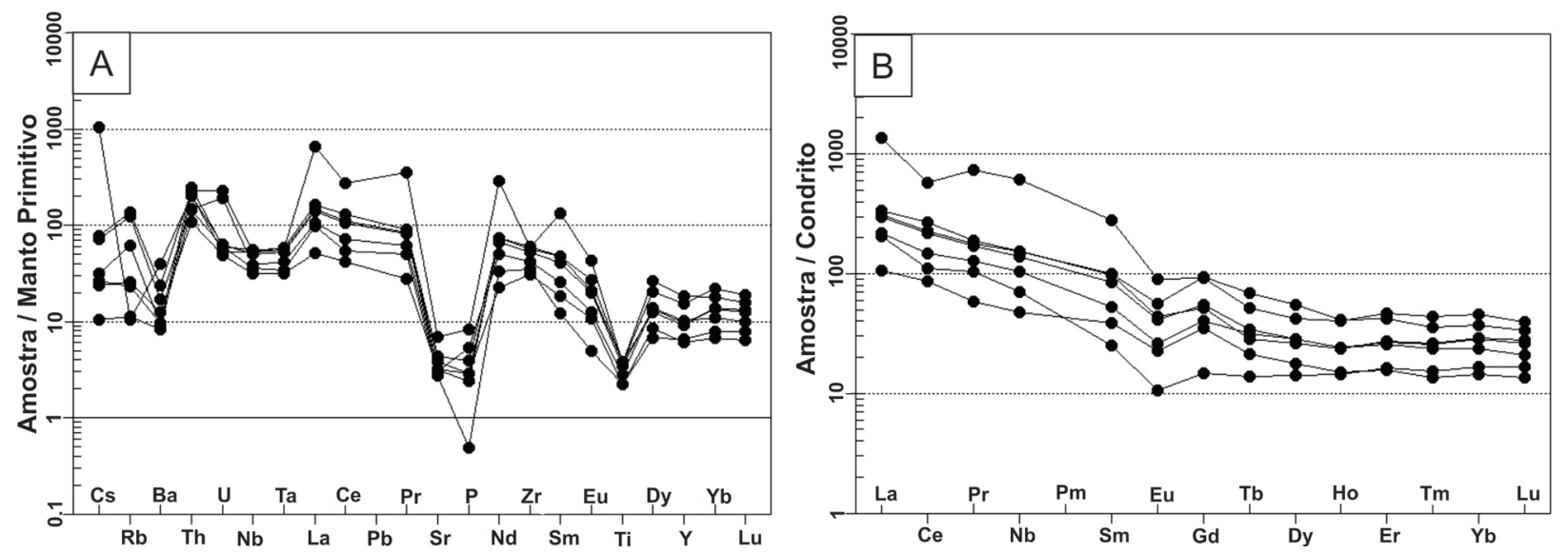

Figura 6. Padrões dos elementos-traço e elementos terras raras para as metavulcânicas da Estrada Real. A) Diagrama multielementar de elementos-traço normalizados pelo Manto Primitivo (Sun \& McDonough, 1989); B) Diagrama de Elementos Terras Raras (ETR) normalizados pelo Con־drito (Boynton, 1984).

Figure 6. Trace and Rare Earth Elements patterns to the metavolcanics from Estrada Real. A) Trace-elements multielementar diagram normalized by Primitive Mantle (Sun and McDonough, 1989); (B) Rare Earth Elements spider diagram normalized by Chondrite (Boynton, 1984).

estudo. A presença de sericita xistos, milonitos e ultramilonitos é frequente na área de estudo, sendo estas rochas geradas por inúmeras zonas de cisalhamento,que cortam as rochas da região deRio de Contas (Guimarães et al., 2008). Segundo Arcanjo et al. (2000), as rochas metavulcânicas e quartzitos eólicos do Grupo Rio dos Remédios se encontram afetados por deformações e o contato entre essas litologias é marcado por zonas de cisalhamento, com indicações de cavalgamento das metaefusivas sobre os metassedimentos. $\mathrm{Na}$ região de Paramirim, próxima a Rio de Contas, as rochas são afetadas por expressivas zonas de cisalhamento, que delimitam o contato entre as rochas do Supergrupo Espinhaço e as rochas do embasamento. As rochas estão quase sempre metamorfizadas na facies xisto verde e fortemente foliadas, embora preservem fenocristais com formas arredondadas.

O principal mecanismo de recristalização identificado nos cristais de quartzo foi a rotação de subgrão, ocorrendo de forma menos frequente, a migração de limite de grão. Evidências de dissolução por pressão e formação de sombras de pressão formadas por quartzo, também foram identificadas. Essas estruturas são comuns em temperaturas entre 400 e $500{ }^{\circ} \mathrm{C}$, o que é compatível com a temperatura de cristalização da cianita em equilíbrio com a granada (em torno de $450^{\circ} \mathrm{C}$ ) (Bucher \& Frey, 1994). A quebra da cianita para cristalização da andalusita, na temperatura acima referida, está relacionada à diminuição de pressão, associada provavelmente, aos eventos finais da inversão da Bacia do Espinhaço.

As feições de alteração hidrotermal observados nas metavulcâncias, como a muscovitização e a sericitização, revelam a ação de fluidos na região, evidências essas também ressaltadas por Teixeira (2005) na região mais a noroeste (cidade de Novo Horizonte), onde também afloram rochas metavulcânicas da Formação Novo Horizonte. A muscovitização (Fig. 7C) é frequente nos cristais de biotita das metavulcânicas ácidas da área de estudo. Este processo ocorre durante a deformação dúctil da rocha e implica na migração de fluidos de forma intercristalina, fazendo com que fases menos estáveis a essas condições sofram processos de transformação por eles induzidos. Assim, há a tendência do cristal de biotita se transformar, segundo os planos de clivagem, quaisquer que sejam eles, considerando que a clivagem facilita a percolação dos fluidos hidrotermais.

A formação da sericita ocorre por instabilidade química dos feldspatos na presença de $\mathrm{H}^{+}, \mathrm{OH}^{-}, \mathrm{K}^{+}$, com formação de quartzo e micas brancas, além da lixiviação de $\mathrm{Na}, \mathrm{Mg}$, Ti, Fe e K (Misas, 2015). Os feldspatos alcalinos são extremamente susceptíveis a ação de soluções hidrotermais (Sial \& McReath, 1984) e em zonas de hidrotermalismo é comum a substituição de feldspatos alcalinos por sericita (Tokashiki, 
Tabela 1. Análises químicas de rocha total de elementos maiores (wt \%), traço (ppm) e terras raras (ppm) das metavulcânicas ácidas da Estrada Real. Abreviação: P.F. = Perda ao fogo.

Table 1. Whole rock chemical analyzes of major (wt \%), trace ( $\mathrm{ppm}$ ) and Rare Earth Elements (ppm) of acidic metavolcanics from Estrada Real. Abbreviation: P.F. = Loss on ignition.

\begin{tabular}{|c|c|c|c|c|c|c|c|}
\hline & RC-05 & $\mathrm{RC}-15$ & RC-16 & RC-18A1 & RC-20 & $\mathrm{RC}-21$ & RC-22 \\
\hline $\mathrm{SiO}_{2}(\%)$ & 84,46 & 80,97 & 78,67 & 82,44 & 77,8 & 80,55 & 80,86 \\
\hline $\mathrm{Al}_{2} \mathrm{O}_{3}$ & 6,64 & 11,89 & 12,19 & 7,01 & 10,6 & 8,51 & 11,15 \\
\hline $\mathrm{Fe}_{2} \mathrm{O}_{3}$ & 4,33 & 7,03 & 7,36 & 4,59 & 8,28 & 6,53 & 6,7 \\
\hline $\mathrm{MnO}$ & 0,04 & 0,06 & 0,01 & $<0,01$ & 0,02 & 0,02 & 0,02 \\
\hline $\mathrm{MgO}$ & 0,11 & 0,01 & 0,08 & 0,02 & 0,26 & 0,31 & 0,01 \\
\hline $\mathrm{CaO}$ & 0,11 & 0,01 & 0,06 & 0,02 & 0,02 & 0,04 & 0,02 \\
\hline $\mathrm{Na}_{2} \mathrm{O}$ & 0,1 & 0,05 & 0,11 & 0,15 & 0,18 & 0,13 & 0,05 \\
\hline $\mathrm{K}_{2} \mathrm{O}$ & 1,09 & 0,49 & 1,21 & 1,73 & 3,08 & 2,63 & 0,43 \\
\hline $\mathrm{TiO}_{2}$ & 0,44 & 0,7 & 0,76 & 0,43 & 0,76 & 0,56 & 0,76 \\
\hline $\mathrm{P}_{2} \mathrm{O}_{5}$ & 0,06 & 0,06 & 0,17 & $<0,01$ & 0,08 & 0,11 & 0,05 \\
\hline $\mathrm{Cr}_{2} \mathrm{O}_{3}$ & $<0,01$ & $<0,01$ & $<0,01$ & $<0,01$ & $<0,01$ & $<0,01$ & $<0,01$ \\
\hline P.F. & 0,64 & 0,85 & 0,99 & 0,99 & 1,53 & 1,35 & 0,82 \\
\hline Total & 98,03 & 102,14 & 101,61 & 97,38 & 102,62 & 100,76 & 100,87 \\
\hline $\mathrm{V}(\mathrm{ppm})$ & $<5$ & $<5$ & $<5$ & 16 & 20 & $<5$ & 16 \\
\hline $\mathrm{Ba}$ & 83 & 262 & 63 & 62 & 158 & 112 & 54 \\
\hline $\mathrm{Sr}$ & 64 & 76 & 138 & 54 & 86 & 60 & 62 \\
\hline $\mathrm{Y}$ & 26,15 & 41,31 & 66,6 & 28,02 & 80,01 & 43,99 & 39,44 \\
\hline Co & 2,6 & 3,1 & 1,6 & 0,7 & 4,1 & 4,1 & 1,1 \\
\hline $\mathrm{Zr}$ & 321 & 561 & 608 & 370 & 626 & 441 & 592 \\
\hline $\mathrm{Zn}$ & $<5$ & $<5$ & $<5$ & $<5$ & $<5$ & $<5$ & $<5$ \\
\hline $\mathrm{Rb}$ & 15,3 & 6,2 & 14 & 37 & 81,2 & 74,3 & 6,8 \\
\hline $\mathrm{Cu}$ & 9 & 8 & 5 & $<5$ & $<5$ & $<5$ & $<5$ \\
\hline $\mathrm{Ce}$ & 69,4 & 175,8 & 463,6 & 89,7 & 215,1 & 119,3 & 185,2 \\
\hline Er & 3,3 & 5,64 & 9,83 & 3,4 & 8,87 & 5,35 & 5,72 \\
\hline $\mathrm{Cs}$ & 0,5 & 0,22 & 0,55 & 0,66 & 1,64 & 1,51 & 0,22 \\
\hline $\mathrm{Ga}$ & 12,4 & 20,1 & 21,2 & 12,1 & 23,9 & 15,7 & 17,6 \\
\hline $\mathrm{Gd}$ & 9,08 & 14,2 & 24,02 & 3,79 & 24,43 & 10,39 & 13,25 \\
\hline $\mathrm{Hf}$ & 8,84 & 14,64 & 15,56 & 8,85 & 15,95 & 11,68 & 15,68 \\
\hline Ho & 1,08 & 1,73 & 2,87 & 1,04 & 2,98 & 1,74 & 1,7 \\
\hline $\mathrm{La}$ & 33 & 91,4 & 424,2 & 63,2 & 105 & 68,2 & 96,4 \\
\hline $\mathrm{Lu}$ & 0,44 & 0,85 & 1,27 & 0,54 & 1,08 & 0,67 & 0,89 \\
\hline Mo & $<2$ & $<2$ & $<2$ & $<2$ & $<2$ & $<2$ & $<2$ \\
\hline $\mathrm{Nb}$ & 20,77 & 33,37 & 36,71 & 23,74 & 34,35 & 25,34 & 34,8 \\
\hline $\mathrm{Nd}$ & 28,4 & 83,1 & 365,2 & 41,9 & 93,1 & 62,1 & 92,4 \\
\hline $\mathrm{Ni}$ & 8 & 8 & 7 & $<5$ & 10 & 8 & 6 \\
\hline $\operatorname{Pr}$ & 7,06 & 20,64 & 89,42 & 12,68 & 23,14 & 15,46 & 21,55 \\
\hline $\mathrm{Eu}$ & 1,66 & 3,02 & 6,68 & 0,77 & 4,15 & 1,91 & 3,23 \\
\hline $\mathrm{Sm}$ & 7,5 & 16,4 & 54,4 & 4,9 & 19,4 & 10,3 & 19,2 \\
\hline $\mathrm{Sn}$ & 2,8 & 3,4 & 2,7 & 2,4 & 3,5 & 3,3 & 3,4 \\
\hline $\mathrm{Ta}$ & 1,17 & 1,93 & 2,1 & 1,25 & 2,14 & 1,54 & 2,04 \\
\hline $\mathrm{Tb}$ & 1,02 & 1,62 & 2,44 & 0,65 & 3,26 & 1,48 & 1,36 \\
\hline Th & 8,7 & 16,3 & 20 & 11,4 & 18,1 & 11,8 & 16,7 \\
\hline $\mathrm{Tl}$ & $<0,5$ & $<0,5$ & $<0,5$ & $<0,5$ & $<0,5$ & $<0,5$ & $<0,5$ \\
\hline $\mathrm{Tm}$ & 0,44 & 0,83 & 1,43 & 0,5 & 1,15 & 0,76 & 0,85 \\
\hline $\mathrm{U}$ & 0,97 & 1,25 & 1,21 & 1,19 & 4,62 & 3,79 & 1,06 \\
\hline W & 2,9 & 4,7 & 3,5 & 2,1 & 3 & 3,5 & 3,5 \\
\hline Dy & 5,67 & 9,13 & 13,67 & 4,59 & 17,54 & 9,23 & 8,45 \\
\hline $\mathrm{Yb}$ & 3 & 6 & 9,6 & 3,5 & 7,8 & 4,9 & 6,1 \\
\hline
\end{tabular}


2015). O epidoto também pode ser produto de alteração hidrotermal dos feldspatos (Sial \& McReath, 1984).

Associada à paragênese hidrotermal ocorre a clorita (Fig. 7D), que pode precipitar diretamente de soluções ou substituir minerais pré-existentes, geralmente ferro-magnesianos, e os minerais opacos. Portanto, a assembléia mineral resultante da alteração hidrotermal é composta por quartzo, muscovita, sericita, clorita, epidoto, minerais opacos e rutilo.

\subsection{Características geoquímicas das metavulcânicas ácidas}

Considerando as características petrográficas e geoquímicas, as rochas metavulcânicas ácidas da área de estudo foram classificadas como metarriolitos, uma vez que essas rochas possuem matriz quartzofeldspática, comum nos riolitos, e a maior parte das amostras apresentam porfiroclastos de quartzo, que seriam resquícios da mineralogia ígnea (riolito).
Comparando as amostras (LR-17, LR18, LR-38 e LR-39) de riolitos da região de Novo Horizonte pertencentes à Formação Novo Horizonte (Teixeira, 2005), com as amostras das rochas metavulcânicas ácidas da Estrada Real (Fig. 8), percebe-se também as semelhanças geoquímicas dos padrões de enriquecimento e anomalias entre as amostras.

As amostras estudadas apresentam uma ampla dispersão dos elementos maiores $\mathrm{Na}_{2} \mathrm{O}$, CaO e $\mathrm{K}_{2} \mathrm{O}$ nos diagramas de Harker, que associada aos conteúdos baixos desses elementos nas metavulcânicas (Tab. 1), refletem a mobilidade dos mesmos (Fig. 4). Da mesma forma, os elementos-traço do tipo LILE (Ba e Rb) apresentam dispersão, enquanto os elementos considerados pouco móveis a imóveis $\left(\mathrm{SiO}_{2^{\prime}}, \mathrm{TiO}_{2^{\prime}}\right.$ $\mathrm{Al}_{2} \mathrm{O}_{5}$ e $\mathrm{FeO}_{2}$, HFSE e ETRs) apresentam trends definidos com o índice de diferenciação ( $\mathrm{Zr}$ ). A existência de zonas de cisalhamento, quefacilitam a percolação de fluídos e consequentemente, as trocas catiônicas nas rochas submetidas às condições metassomáticas, provavelmente favoreceram a lixiviação dos elementos mais móveis, gerando a dispersão nos diagramas.

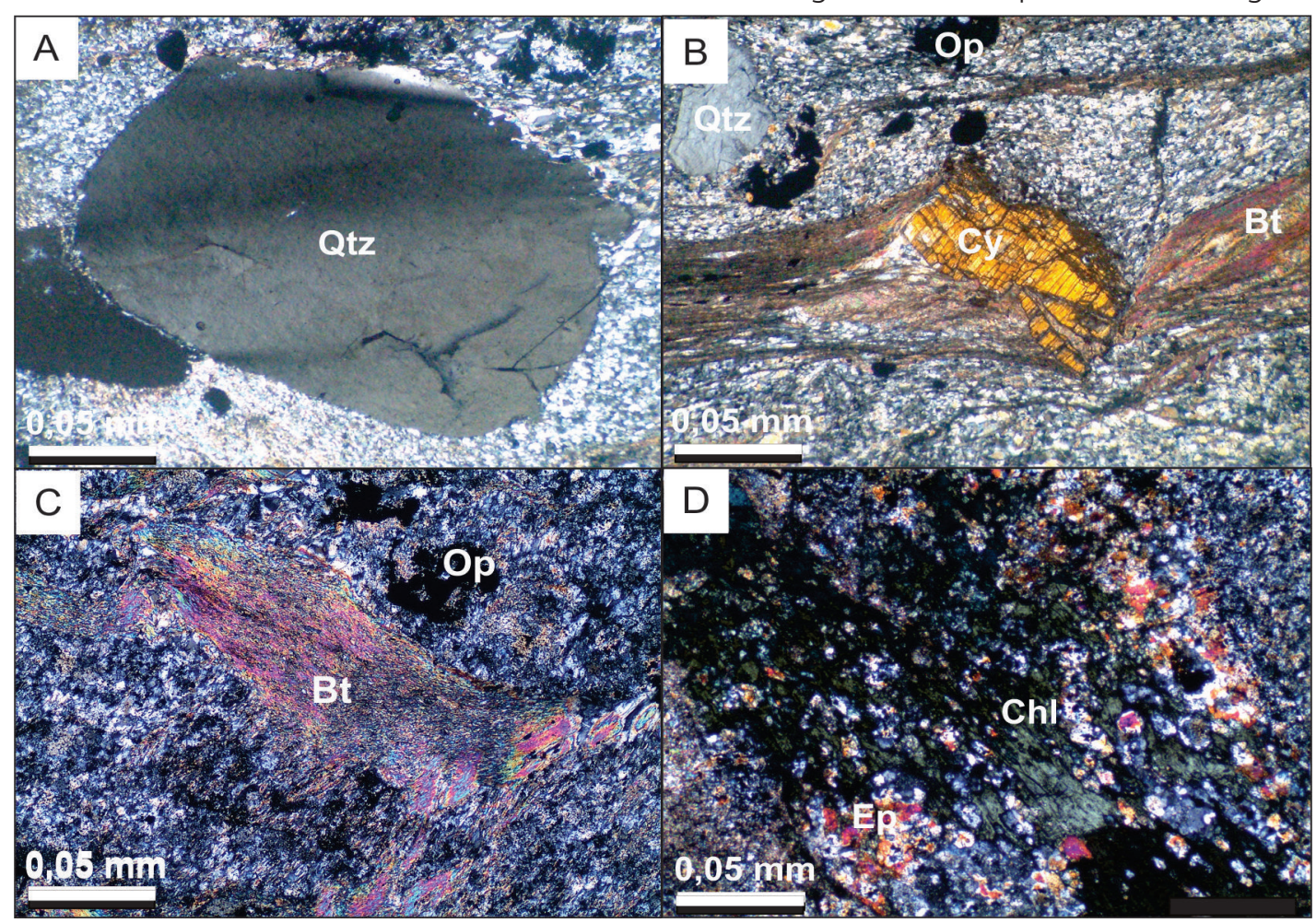

Figura 7. Fotomicrografias das rochas metavulcânicas ácidas. A) Porfiroclasto de quartzo com presença de subgrãos; B) Cristal de cianita rotacionado; C) Processo de muscovitização nos cristais de biotita; D) Clorita hidrotermal (abreviações Segundo Whitney \& Evans, 2010). Luz polarizada (4X).

Figure 7. Photomicrographies of acidic metavolcanic rocks. A) Quartz porphyroclast with presence of subgrains; B) Rotated cyanite crystal; C) Muscovite process in the biotite crystals; D) Hydrothermal chlorite (abbreviations Whitney \& Evans, 2010). Polarized light (4X). 


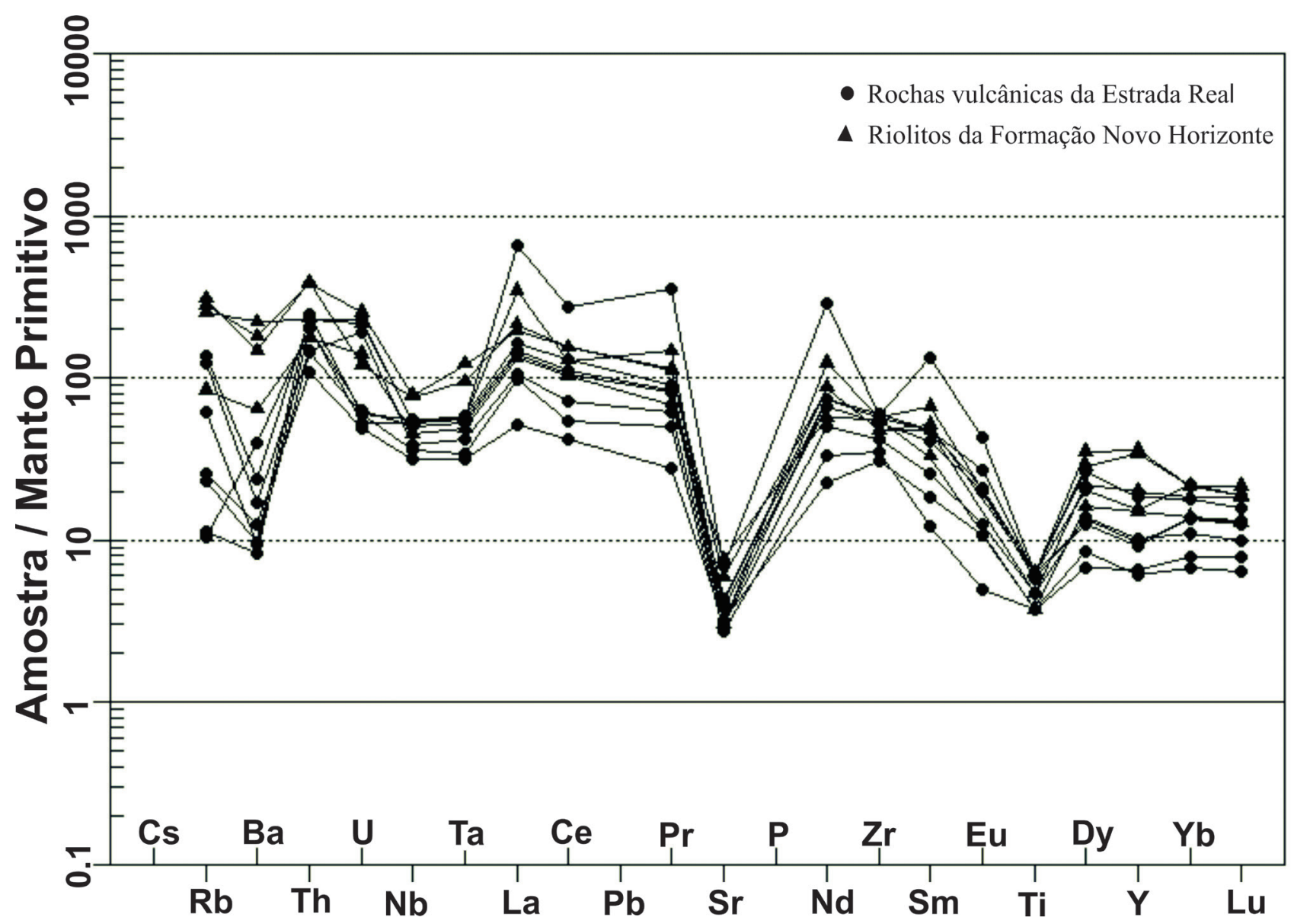

Figura 8. Diagrama multielementar de elementos-traço normalizado pelo manto primitivo (Sun \& McDonough, 1989) para as amostras das metavulcânicas da Estrada Real e as amostras de riolitos (LR-17, LR-18, LR-38 e LR-39) da região de Novo Horizonte.

Figure 8. Trace-elements multielementar diagram normalized by the Primitive Mantle (Sun \& McDonough, 1989) to metavolcanics samples from Estrada Real and rhyolites samples (LR-17, LR-18, LR-38 and LR-39) from Novo Horizonte region.

Apesar de existir um trend na correlação do $\mathrm{SiO}_{2}$ com o $\mathrm{Zr}$, e de $\mathrm{SiO}_{2}$ com o $\mathrm{Al}_{2} \mathrm{O}_{3^{\prime}}$ as correlações são negativas e não representam um trend clássico de cristalização fracionada. Em todos os diagramas com trends de correlação positiva, dois grupos de amostras podem ser observados, um mais empobrecido (Grupo 1) e outro mais enriquecido (Grupo 2). O Grupo 1 (amostras RC05, RC-18A1 e RC-21) é formado por rochas que apresentam valores anomalamente baixos de $\mathrm{Al}_{2} \mathrm{O}_{3}$ e altos de $\mathrm{SiO}_{2}$. No Grupo 1 é evidente também, os valores mais baixos de elementostraço comparado com o Grupo 2. O Grupo 2 (RC-15, RC-16, RC-20 e RC-22) por sua vez, apresenta valores um pouco mais baixos de $\mathrm{SiO}_{2}$ e mais altos de $\mathrm{Al}_{2} \mathrm{O}_{3}$ que o Grupo 1. Apresentam também, valores mais altos de elementos-traço. Cabe ressaltar que uma das amostras do Grupo 2 (RC-16) apresenta valores anomalamente altos de $\mathrm{P}_{2} \mathrm{O}_{5}$ e de ETRs, devido à presença dos minerais acessórios monazita, apatita e zircão, que são minerais enriquecidos nestes elementos.

De acordo com as características geoquímicas citadas acima, as amostras do Grupo 1 possuem uma quantidade anomalamente alta de $\mathrm{SiO}_{2}$, sugerindo a assimilação de uma porção arenítica pelo magma riolítico para a formação desse grupo. A maioria das rochas do Grupo 1 não apresentam aluminossilicatos (andaluzita e cianita), comuns no Grupo 2, embasando a hipótese de assimilação de um material pobre em $\mathrm{Al}_{2} \mathrm{O}_{3}$ e rico em $\mathrm{SiO}_{2}$.

O grupo 2 por sua vez é caracterizado pela ocorrência de aluminossilicatos e pseudomorfos de granada na sua mineralogia, incomum em rochas riolíticas. Essa mineralogia pode ser explicada pela assimilação de rochas pelíticas ricas em alumínio por parte do magma riolítico. As 
rochas sedimentares, como já citado, formavam a base da Bacia do Espinhaço (Formação Serra da Gameleira), quando houve a extrusão do magma riolitico. Fragmentos e até mesmo lentes de rochas sedimentares (arenitos) podem ser encontrados inseridos na unidade metavulcânica ácida da Formação Novo Horizonte, sendo mais uma evidência da assimilação de fragmentos sedimentares.

Os padrões para elementos-traço observados no diagrama multielementar (Fig. 6A) são caracterizados por expressivas anomalias negativas de $\mathrm{Nb}, \mathrm{Ta}$, Sr, P e Ti. A anomalia negativa de Nb, Ta e Ti é característica de magmas de zonas de subducção, enquanto que o padrão de ETRs é característico de magmas alcalinos e intraplaca (Fig. 9A). A instalação do rifte do Espinhaço se dá durante o Estateriano, logo após a Orogênese Paleoproterózoica, onde segmentos crustais arqueanos do Cráton São Francisco colidiram, registrando o pico em torno de 2.0 Ga (Barbosa \& Sabaté, 2003). Dessa forma, no momento da instalação do rifte do Espinhaço, a fonte do magmatismo alcalino sofreu interação com um manto previamente modificado por zona de subducção (manto metassomatizado), gerando as características geoquímicas típicas de subducção impressas nas rochas estudadas.

A anomalia negativa de $\mathrm{Sr}$ pode estar relacionada a alta mobilidade desse elemento, considerando que houve empobrecimento nos principais elementos móveis da rocha, associado ao evento hidrotermal que afetou a região. Além disso, as anomalias de Sr, P e Ti podem ainda ter sido intensificadas pelo fracionamento de plagioclásio, apatita, minerais opacos/ rutilo,respectivamente, durante a geração dos riolitos (protólitos das metavulcânicas).

O padrão de distribuição dos ETR (Fig. 6B) mostra que as rochas apresentam enriquecimento em ETRL em relação aos ETRP. A anomalia negativa de Eu observada sugere fracionamento de plagioclásio. A amostra RC-16 apresenta maior enriquecimento em ETRLs em relação aos ETRPs e anomalia negativa de Ce, sendo estas características atribuídas a presença de monazita na rocha.

No diagrama de discriminação geotectônica $\mathrm{Y}+\mathrm{Nb}$ vs. Rb (Fig. 9A), as amostras plotam em dois campos denominados de VAG (granitos de arco vulcânico) e WPG (intra-placa), sendo estes pós-colisionais.

O diagrama de Eby (1992), através da relação entre vários elementos traço, define dois tipos de magmatismo do tipo A: (i) A1, cuja origem é eminentemente mantélica e (ii) A2, produzido por fusão parcial de crosta continental. Os produtos de mistura entre material mantélico e crustal também são enquadrados nesta categoria. As amostras das rochas metavulcânicas ácidas da Formação Novo Horizonte plotam no campo Tipo A2 (Fig. 9B), sugerindo fusão parcial da crosta continental.

A distribuição das amostrasem dois campos no diagramade Pearce et al. (1984) sugere mistura de fontes para as metavulcânicas de Rio de Contas, com contribuição de material crustal e mantélico. Provavelmente, no momento da instalação do rifte do Espinhaço houve a interação da fonte do magmatismo alcalino com um manto previamente modificado por zona de subducção (manto metassomatizado). O padrão geoquímico das rochas da Formação Novo Horizonte podem ser relacionados à zona de subducção (anomalias negativas de Nb, Ta e Ti) e à ambiente alcalino intraplaca (padrão de ETR), o que corrobora para a hipótese de mistura de fontes. Assim, a mistura de material crustal com material mantélico é atribuída para a geração das rochas da Formação Novo Horizonte, sendo o motivo pela qual as amostras plotam em campos diferentes no diagrama de Pearce et al. (1984).

Arcanjo et al. (2000) afirmam que rochas da Formação Novo Horizonte estão relacionadas à fusão crustal com ou sem influência de magmatismo mantélico. Segundo Teixeira (2005), as rochas vulcânicas/subvulcânicas da Formação Novo Horizonte constituem parte de um magmatismo peraluminoso e alcalino do tipo A2, com importante contribuição crustal. Magmas desse tipo ocorrem dentro de um amplo espectro de ambientes geotectônicos, desde pós-colisional até anorogênico. bastante compatível com o magmatismo que produziu as vulcânicas/subvulcânicas da Formação Novo Horizonte. 

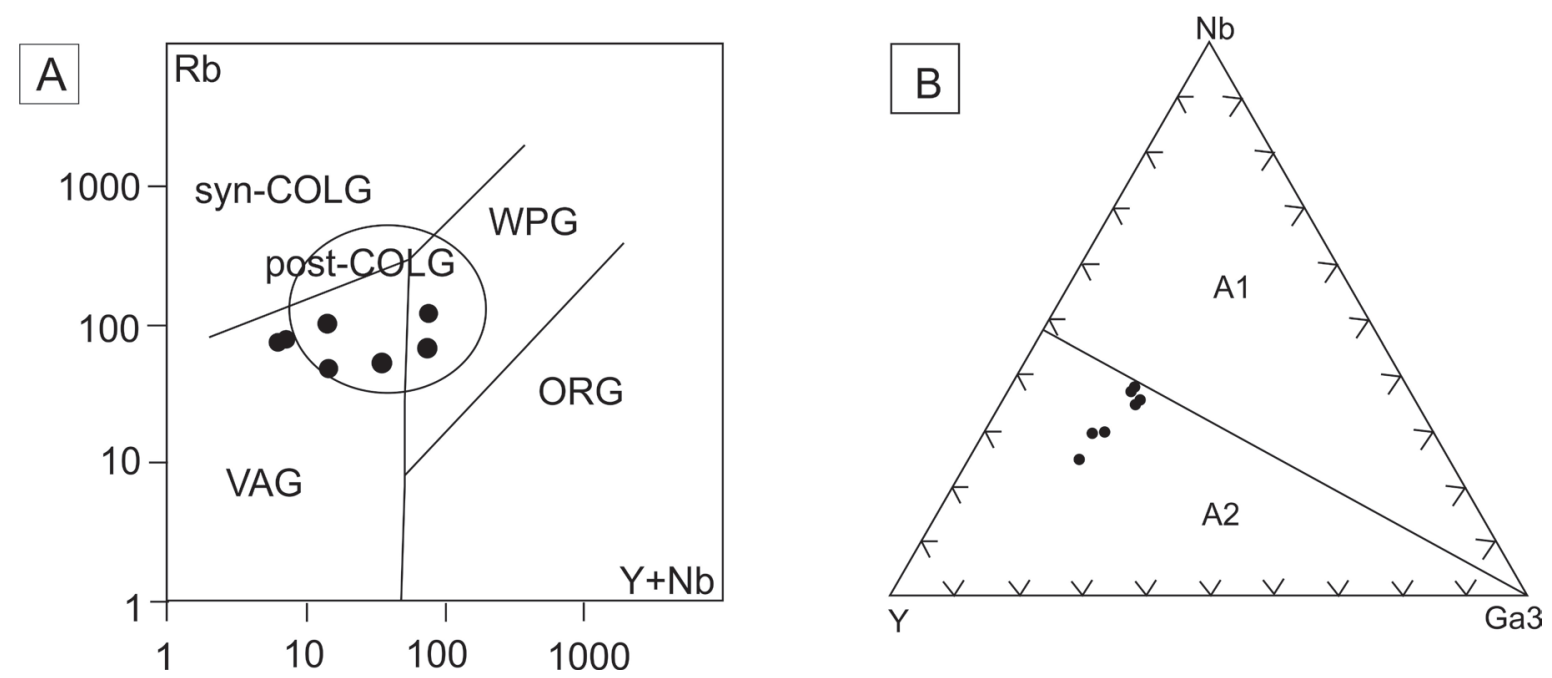

Figura 9. Diagramas discriminantes. A) Diagrama $\mathrm{Y}+\mathrm{Nb} \times \mathrm{Rb}$ discriminante de ambiência geotectônica (Pearce et al., 1984, com domínios tectônicos de Pearce, 1996), para as metavulcânicas ácidas. WPG (Granitos Intraplaca), VAG (Granitos de Arco Vulcânico), ORG (Granitos de Cordilheira Oceânica), SYN-COLG (Granitos Sin-colisionais) e POST-COLG (Granitos Pós-Colisionais); B) Diagrama discriminando o magmatismo do Tipo A2 para as metavulcânicas ácidas da Estrada Real (Eby, 1992).

Figure 9. Discriminant diagrams. A) $R b \times Y+N b$ geotectonic environment discriminant diagram for acid metavolcanics (Pearce et al., 1984, with tectonic domains of Pearce, 1996). WPG (Intraplate Granites), VAG (Volcanic Arc Granites), ORG (Oceanic Ridge Granites), SYN-COLG (Sin-Collisional) and POS-COLG (Pos-Collisional); B) Y-Nb-Ga3 diagram discriminating A2 Type magmatism for acid metavolcanics rocks from Estrada Real (Eby, 1992).

\section{Conclusões}

As metavulcânicas ácidas da Estrada Real são rochas com cores em tons de cinza e cinza escuro, com textura afanítica e foliação incipiente a bem marcada.

Petrograficamente,

apresentam texturas blasto-porfirítica, porfiroblástica e lepidoblástica. A mineralogia é constituída por quartzo, feldspatos, biotita, andaluzita, cianita, pseudomorfo de granada, sericita, clorita, epidoto, muscovita, monazita, apatita, zircão, minerais opacos/rutilo. A foliação é marcada pelos minerais de biotita orientados, caracterizando a textura lepidoblástica.

Os dados petrográficos associados as análises químicas indicam que o protólito das metavulcânicas corresponde a riolito. Os dados geoquímicos atestam expressivas anomalias negativas de $\mathrm{Nb}, \mathrm{Ta}, \mathrm{Sr}, \mathrm{P}$ e Ti no diagrama multielementar de elementos-traço. O padrão de ETRs das metavulcânicas ácidas mostra enriquecimento em ETRLs em relação aos ETRPs. Essas rochas foram formadas em ambiente intraplaca, um rifte continental assumido para a Chapada Diamantina, e estão associadas a um magmatismo do Tipo A2, indicando um processo de fusão parcial crustal para a gênese das metavulcânicas ácidas e interação do magmatismo alcalino com um manto previamente modificado por zona de subducção (manto metassomatizado).

De acordo com as características geoquímicas das rochas metavulcânicas, as amostras são representadas em dois Grupos: o Grupo 1 com amostras mais empobrecidas em $\mathrm{Al}_{2} \mathrm{O}_{3}$ e consequentemente, mais enriquecida em $\mathrm{SiO}_{2}$; o Grupo 2, com amostras que apresentam valores um pouco mais baixos de $\mathrm{SiO}_{2}$ e mais altos de $\mathrm{Al}_{2} \mathrm{O}_{3}$ que o Grupo 1. Os dados químicos das amostras do Grupo 1 indicam que as rochas deste grupo apresentam o registro de processos de assimilação crustal de rochas areníticas por parte do magma riolítico. A geoquímica do Grupo 2 evidencia processo de assimilação crustal de rochas pelíticas ricas em $\mathrm{Al}_{2} \mathrm{O}_{3}$ por parte do magma riolítico.

A Orogênese Brasiliana ocorrida no Neoproterozóico na região de Rio de Contas gerou o espessamento crustal, decorrente da tectônica de cavalgamento e a formação de inúmeras zonas de cisalhamento no contexto geológico da região, e consequentemente, o metamorfismo regional e processos hidrotermais associados, 
que propiciaram modificações químicas nas rochas da região de Rio de Contas, através da ação de fluidos ou decorrentes de reações metamórficas relacionadas ao evento tectônico.

Agradecimentos. À Fundação de Apoio à Pesquisa e à Inovação Tecnológica do Estado de Sergipe -FAPITEC/SE pela concessão da bolsa de mestrado. Aos colaboradores: Antônio Garcia (DGEOL/PROGEOLOGIA-NUPEG/UFS) pelo apoio com equipamentos necessários para o preparo das amostras, Joilma Prazeres Santos (UFOB) pelas importantes discussões e contribuições geológicas, Reginaldo Alves dos Santos (CPRM) pela ajuda na elucidação de dúvidas no mapa geológico, Márcio Vinicius Dantas (PROGEOLOGIA-NUPEG/UFS) pela colaboração no corte de amostras e Emilayne Cristina pela colaboração na edição dos mapas.

\section{Referências}

Almeida, F.F.M. 1977. O Cráton do São Francisco. Revista Brasileira de Geociências, 7:349-364.

Allen, P.A. \& Allen, J.R. 1990. Basin Analysis Principles and Applications. Blackwell (Basil), Oxford, $451 \mathrm{p}$.

Arcanjo, J.B.A., Varela, P.H.L., Martins, A.A.M. Loureiro, H.S.C. \& Neves, J.P. 2000. (Org.) Projeto Vale do Paramirim: Estado da Bahia. Programa Levantamentos Geológicos Básicos do Brasil - PLGB. Convênio CBPM/CPRM. Escala 1:200.000. Relatório interno. CPRMBahia, Salvador.

Barbosa, J.S.F. 2012. Geologia da Bahia: pesquisa e atualização, 2v.: iL. color. - (Série de publicações especiais; 13). Salvador, CBPM, 33-85 p.

Barbosa, J.S.F. \& Sabaté P. 2003. Colagem Paleoproterozóica de placas arqueanas do Cráton do São Francisco na Bahia.

33(1-Suplemento):7-14.

Barbosa, J.S.F., Sabaté, P. \& Marinho, M.M. 2003. O Cráton do São Francisco na Bahia: uma síntese. Revista Brasileira de Geociências, 33(1):3-6.

Bastos-Leal, L.R. 1998. Geocronologia U/Pb (Shrimp), 207Pb/206Pb, Rb-Sr, Sm-Nd e K-Ar dos Terrenos Granito Greenstone do Bloco do
Gavião: Implicações para Evolução Arquena e Proterozóica do Cráton do São Francisco, Brasil. São Paulo, 21 p. Tese de Doutorado, Programa de Pós-Graduação em Geoquímica e Geotectônica, Instituto de Geociências, Universidade Estado de São Paulo.

Boynton, W. V. 1984. Geochemistry of rare earth elements: meteorite studies. In: Henderson P. (Ed.) Rare Earth elements geochemistry. Amsterdam, Elsevier, p. 63-114.

Bucher, K. \& Frey, M. 1994. Petrogenesis of Metamorphic Rocks. Berlin, Heidelberg, Springer-Verlag, 315p.

CPRM. Companhia de Pesquisas e Recursos Minerais. 2013. Mapa Geológico Folha Rio de Contas - 1:100.000. Disponível em: http:// www.cprm.gov.br. Arquivo consultado em 10 de Fevereiro de 2015.

Cruz, S.C.P. \& Alkmim, F.F. 2006. The tectonic interaction between the Paramirim Aulacogen and the Araçuaí Belt, São Francisco Craton region, Easter Brazil. Anais da Academia Brasileira de Ciências, 78(1):151-173.

Cruz, S.C.P., Dias, V.M. \& Alkmim, F.F. 2007. A interação tectônica embasamento/cobertura em aulacógenos invertidos: um exemplo da Chapada Diamantina Ocidental. Revista Brasileira de Geociências, 37(4 - suplemento): 111-127.

Danderfer, A. \& Dardenne, M.A. 2002. Tectonoestratigrafia da bacia Espinhaço na porção centro-norte do Cráton do São Francisco: registro de uma evolução poliistórica descontínua. Revista Brasileira de Geociências 32(4):449-460.

Danderfer, A., Waele B.D., Augusto, J., Pedreira, A.J. \& Nalini, H.A. 2009. New geochronological constraints on the geological evolution of Espinhaço basin within the São Francisco Craton-Brazil. Precambrian Research, 170:116-128.

Dussin I.A. \& Dussin T.M. 1995. Supergrupo Espinhaço: Modelo de Evolução Geodinâmica. Geonomos, 1:19-26.

Eby, N.E. 1992. Chemical subdivision of the A-type granitoids: Petrogenetic and tectonic implications. Geology, 20:641-644.

Guimarães, J.T., Martins, A.A.M., Andrade, Filho, E.L., Loureiro, H.S.C., Arcanjo, J.B.A., Abram, 
M.B., Silva M.G. \& Bento, R.V. 2008. Projeto Ibitiara-Rio de Contas. Série Arquivos Abertos; 31, CPRM-Bahia. Salvador.

Hastie, A.H., Kerr, A.C., Pearce, J.A., Mitchell, S.F. 2007. Classification of altered volcanic island arc rocks using immobile trace elements: development of the Th-Co discrimination diagram. Journal of Petrology, 48:2341-2357.

IBGE. Instituto Brasileiro de Geografia e Estatística. 2015. Carta Topográfica de Rio de Contas, Bahia. Região Nordeste do Brasil - 1:100.000. Disponível em: http://wwwibge. gov.br. Arquivo consultado em 15 de Janeiro de 2015.

Jardim de Sá, E.F. 1981. A Chapada Diamantina e a Faixa Santo Onofre: um exemplo de tectônica intraplaca no Proterozoico Médio do Cráton do São Francisco. In: Inda, H., Marinho, M.M. \& Duarte F.B. (Orgs.), Geologia e Recursos Minerais do Estado da Bahia; Textos Básicos, vol. IV. Salvador, SME/CPM, 111-120 p.

Martins-Neto, M.A. 1998. O Supergrupo Espinhaço em Minas Gerais: registro de uma bacia rifte-sag do paleo/mesoproterozoico. Revista Brasileira de Geociências, 28(2):151168.

Martins-Neto, M.A. 2000. Tectonics and sedimentation in a paleo/mesoproterozoic rift-sag basin (Espinhaço basin, southeastern Brazil). Precambrian Research, 103:147-173.

Misas, C.M.E. 2015. Geologia e alteração hidrotermal nas rochas vulcânicas e plutônicas paleoproterozoicas na porção sul da Província Mineral do Tapajós (PA). São Paulo, 26-32 p. Tese de Doutorado, Programa de PósGraduação em Geoquímica e Geotectônica, Instituto de Geociências, Universidade Estado de São Paulo.

Pearce J.A. 1996. Sources and settings of granitic rocks. Episodes, 19:120-125.

Pearce, J.A., Harris, N.B.W. \& Tindle, A.G. 1984. Trace element discrimination diagrams for tectonic interpretation of granitic rocks. Journal of Petrology, 25:956-983.
Pedreira, A.J. 1994. O Supergrupo Espinhaço na Chapada Diamantina no Centro-Oriental, Bahia: sedimentologia, estratigrafia e tectônica. São Paulo, 81 p. Tese Doutorado, Programa de Pós-Graduação em Geoquímica e Geotectônica, Instituto de Geociências, Universidade de São Paulo.

Schobbenhaus, C. 1996. As tafrogêneses superpostas Espinhaço e Santo Onofre, Estado da Bahia: Revisão e novas propostas. Revista Brasileira de Geociências, 26(4):265276.

Schobbenhaus, C., Hoppe, A., Baumann, A. \& Lork, A. 1994. Idade U/Pb do vulcanismo Rio dos Remédios, Chapada Diamantina, Bahia. In: CONGRESSO BRASILEIRO DE GEOLOGIA, 38, 1994, Balneário Camboriú. Boletim de Resumos Expandidos, Camboriú, 2:397-398.

Sial, A.N. \& McReath, I. 1984. Petrologia ígnea: os fundamentos e as ferramentas de estudo. Volume I. Salvador, SBG; CNPq; Bureau, 179p.

Sun, S.S. \& McDonough, W.F. 1989. Chemical and isotopic systematics of oceanic basalts: implications for mantle composition and processes. In: Saunders, A.D. \& Norry, M.J. (Eds.). Magmatism in ocean basins. Geological Society of London, Spec. Pub., 42: 313-345.

Teixeira, L. R. 2005. Projeto Ibitiara- Rio de Contas: relatório temático de litogeoquímica. Salvador: CPRM, 33 p. Programa Levantamentos Geológicos Básicos do Brasil - PLGB. Relatório interno.

Tokashiki, C.C. 2015. Mineralizações LowEintermediate-sulfidation de ouro e de metais de base em domos de riolito paleoproterozoicos na porção sul da província mineral do Tapajós. São Paulo, 162p. Tese de Doutorado, Programa de Pós-Graduação em Recursos Minerais e Hidrogeologia, Instituto de Geociências, Universidade Estado de São Paulo.

Whitney, D.L. \& Evans, B.W. 2010. Abbreviations for names of rock-forming minerals. American Mineralogist, 95:185-187. 